\title{
Integrating Religious Moderation Value through Learning Process in Islamic Higher Education (An Analysis to the Lecturer's Perspective)
}

\author{
Nirwana $^{1}$, Muhlis $^{2}$, Sriyanti Mustafa ${ }^{3}$, Diarti Andra Ningsih ${ }^{4}$ \\ \{nirwana.nirwana@uin-alauddin.ac.id ${ }^{1}$ \} \\ Universitas Islam Negeri Alauddin Makassar, Indonesia ${ }^{1}$ \\ Institut Agama Islam Muhammadiyah Sinjai ${ }^{2,3,4}$
}

\begin{abstract}
Islamic Higher Education are required to develop religious moderation throughout all campus components, especially for the students by integrating the values of religious moderation in the learning process. therefore, it is important to see how the lecturer's perceptions are and how the strategies they use to integrate religious moderation in the learning process. This study used a qualitative descriptive approach through observation and interviews to the lecturers at Islamic institute of Muhammadiyah Sinjai. The researcher found the fact that most of the lecturers had read the literature about religious moderation, only a small part who had never read it, most had not applied it to the learning process and a small proportion had begun to integrate it into the learning syllabus and integrated it into the courses that they taught. For the institution it can be a reference to provide a wider understanding of religious moderation in Islamic higher education, and for lecturers it become a motivation to always study and understand religious moderation and to try to make innovation and integrate certain values in the learning process.
\end{abstract}

Keywords: Religious moderation, learning process, lecturer's perspective

\section{Introduction}

University as the centre of knowledge transformation and also the place for the forging of future national leaders of the nation is always demanded to be dynamic. Differences in understanding and thinking are common. There are many study groups both scientific and religious. The student period is a period of independence in thinking, maturing and selfdiscovery. However, we cannot deny that the student period and the campus world are the times when they will build their frame of mind by reading various realities on campus. Various social phenomena either in the form of conflict or political momentum will automatically shape their mindset [1]. Therefore it needs a clear framework and orientation in carrying out various policies that must be supported by all campus components, one of which is the contribution and perception of lecturers in giving lessons in class, so that students are not easily exposed to various extreme ideologies that are not in line with the values of diversity that must be implemented in Indonesia as a country with a diverse population [2].

Recently, the world of higher education has been shocked by the results of research which states that some campuses in Indonesia and their students are exposed to radicalism. Setara Institut mentions that 10 well-known state universities are exposed to radicalism. The ten 
universities include UI Jakarta, IPB, ITB, UGM Yogyakarta, UNY, Unibraw Malang, Unair, Unram, UIN Jakarta and UIN Bandung. The highest level occurred at IPB and ITB. Meanwhile, in UIN Jakarta and UIN Bandung. Another news that added to the impression of exposure to the campus world was conveyed, R Ryamizard Ryacudu, when he was still the Minister of Defense, who said $23.4 \%$ of Indonesian students were exposed to radicalism [3].

The religious moderation promoted by the Ministry of Religion today aims to think inclusively and restore our spirit of mutual cooperation as members of society. The values of religious moderation, as in the book published by the Ministry of Religion's Research and Development and Training Agency entitled Religious Moderation (2019), state that there are 4 main values that are at the core of the religious moderation movement, namely national commitment, harmony, anti-violence and wisdom towards local culture [4].

Several studies on religious moderation for the millennial generation were also conducted outside Jakarta. One of them is in Central Sulawesi (Palu). A Professor of IAIN Palu, Zainal Abidin, said that there are six principles that need to be developed in religious moderation education, namely humanistic, realistic, inclusive, fair, cooperative and tolerant attitudes. $\mathrm{He}$ also offers four steps to develop religious moderation for the millennial generation [5]. First, the benefits of the development of social media technology in spreading religious moderation; second, involving the millennial generation in positive activities in society; third, there needs to be adequate space for dialogue for the millennial generation both in educational institutions, at home and in society; fourth, optimizing the function of the family as a positive character building institution.

Implementing student thoughts that are in accordance with the expectations of the nation and in line with the concept of religious moderation initiated by the Ministry of Religion is not easy. It takes the efforts of the entire academic community to make this happen. Apart from the policies of the policy makers, that great hope is also on the shoulders of the teaching staff or lecturers [6]. Lecturers are professional educators and scientists with the main task of transforming, developing, and disseminating science, technology, and arts through education, research, and community service [7]. The opportunity for lecturers to construct students' minds is enormous, because every week they face students directly. Therefore, it is important for lecturers to understand the concept of religious moderation.

On this case, the authors are interested in conducting research on the Integration of the Value of Religious Moderation through the Learning Process in Islamic Higher Education which. The objective of the research is analysing the lecturer's perspective toward the concept of religious moderation in the learning process and how they try to integrate it in the course.

\section{Method}

This research used qualitative approach which was intended to understand the phenomena experienced by research subjects. This research produces descriptive data in the form of words in spoken and written form from people and their observed behaviour. This research was descriptive qualitative in nature, namely analysing and describing objectively and accurately about the activities, events and circumstances of the research [8]. In order to be appropriate the researcher used research instruments to obtain information as expected and produce reliable data. As for the main instruments in this study are the researchers themselves and various media such as observation guidelines, interviews and documentation tools. 
The methods that researchers used in data analysis techniques in this study are the interactive models of Miles and Huberman, namely data analysis is carried out when data collection is taking place, and after data collection in a certain period is by data reduction, namely summarizing and selecting the main things and focusing on the important things and looking for themes that are considered important and relevant. Then the display or data presentation is a form of short descriptions, charts, and the like which is a continuation after the data is reduced and through the presentation of the data, the data is organized, arranged in a relationship pattern, so that it will be easier to understand. The last is verification or conclusion is the conclusion that after the data is patterned, focused and arranged systematically in a narrative form, then through the induction method, the data is concluded. So that the meaning of the data can be found in the form of interpretations and arguments. Conclusions were also verified throughout the study. Conclusions drawn if there are deficiencies will be added.

\section{Results and Discussion}

\subsection{Lecturer's Perceptions toward the Concept of Religious Moderation}

The results of the research to the lecturer of IAIM Sinjai, the researcher found several facts that the concept of religious moderation is not a new issue. Generally, they have got the concept of religious moderation from a book published by the ministry of religion and others literature. There are also those who understand the concept of religious moderation from symposium, journals, newspapers and social media. The lecturers basically agreed with the concept of religious moderation. They gave their view that the concept of religious moderation is a solution to the current state of the nation, which has many potential conflicts in the name of religion. Indonesian is a pluralistic nation in the form of a unitary state in which consist of many ethnic groups, races and religions.

Nurhasana, one of the IAIM Sinjai lecturers, gave the view that there are three things that become benchmarks for religious moderation. First, return to the main core of religious teachings, namely human values. Every religion, the core of its teachings, invites to respect and protect the dignity of humanity. "If there are religious teachings that contradict the core teachings of religion then this is excessive and extreme. Second, mutual agreement. Humans still have limitations. That is why God presents diversity, so that one another can perfect each other. Diversity is God's will. Diverse human beings need agreement. In Islamic teachings it is known as a very strong bond. The main essence of religious teachings is how people with various backgrounds can live together in an orderly manner. "The purpose of religion is presented in order to create public order in the midst of various shared lives. In addition, Amran stated that the concept of religious moderation is an important thing that must be understood together, so that everybody will not easily judge one another when they have different understandings in religion.

The pluralism of the Indonesia requires a mature concept to be applied so that there is no friction between religions. This is in line with the opinion of a lecturer who said that if understood properly, the concept of religious moderation is in accordance with the pluralistic conditions of Indonesian society [9]. The concept of religious moderation is good, because of the tolerance no organization is mutually marginalized.

Religious moderation is also interpreted as a concept of understanding religion in a balanced manner. Syamsir one of senior lecturer in IAIM said that the concept of religious 
moderation is good because it teaches us to understand religious teachings in a fair and balanced manner so as to minimize the occurrence of practice behaviour that is not in accordance with religious teachings, in order to avoid extreme or excessive behaviour when implementing it. Apart from that, religious moderation is also considered capable for preventing extreme and radical understandings, this was conveyed by several lecturers. Ashar and Nurwahida conveyed their similar perception that the concept of religious moderation is necessary so that extreme and radical understanding of religion can decrease. Religious moderation is a concept in which our perspective on religion is moderate, namely understanding and practicing religious teachings without being extreme and not excessive. Religious moderation can be used as a forum as well as efforts to prevent various attitudes and practices from radical religious understandings, which have the potential to become disturbance to religious harmony.

In essence, the concept of religious moderation is considered very well in accordance with what is perceived by Hamka, saying that religious moderation is very good today, because it guides followers of religions, especially Islam, to address issues wisely, so that they always take the middle path on the phenomenon of political life in particular. In Indonesia. Even so, a concept certainly gets different views from all circles as conveyed by Laily Qadrianti, the concept of religious moderation in Indonesia has not been going well because there is still some discrimination in the name of religion. There are different perceptions of religious moderation, of course, this is based on the views and social realities that occur around them. However, this does not become an obstacle to realizing the concept of religious moderation in Indonesia.

\subsection{Integration of the Concept of Religious Moderation in the Learning Process}

Based on data collected from this research, some of the lecturers at IAIM Sinjai have applied various methods or ways to integrate the concept of religious moderation in the learning process. As stated by Muhammad Ikbal and Muhammad Azhar Nur:

"How to integrate the concept of religious moderation in the learning process by integrating empirical studies of Islam before, during, or after learning, for example examining verses, sirah nabawiyah which concerns how Islam views and treats people in social interaction"

"The way to integrate the concept of religious moderation in the learning process is to provide an example or explanation of the importance of religious moderation so that there is no misinterpretation of taking attitudes in religion because sometimes extreme and radical attitudes in religion deviate far from the teachings of religion itself. It can even lead to conflict in religion.

In general, the integration of religious moderation must be supported by all relevant stakeholders, especially in the context of a multicultural society. First, making educational institutions as the basis for religious moderation laboratories. Educational institutions are very appropriate to be laboratories for religious moderation [10]. As it is understood, the Indonesian nation is a nation that has various ethnicities and religions. Indonesia has its own unique characteristics, but it is full of challenges. As for its strategic steps; 1) Religious moderation must be the government's concern in making the narrative of the National Long-Term Development Plan (RPJPN); 2) Involving educational institutions: Pesantren, madrasah and schools and other non-formal institutions in strengthening human values, values of religious harmony, and religious moderation; 3) Developing religious literacy and interfaith education; 4) Schools must multiply the practice of different religious experiences so that they can establish cooperation between religious adherents. Second, the socio-religious moderation approach in religion and state [3]. 
Meanwhile, according to Meisaraswaty, Amran, Nurwahida, S.HI., ME, and Hamka mention that the way to integrate religious moderation can be started in a simple instruction in the classroom, for example:

"Always linking learning materials related to religious moderation or at the end of learning provides an understanding of moderation."

"How to implement / integrate religious moderation in learning by instilling Islamic religious values in students."

"Integrating with the learning process is more on entrusting Islamic values which are rahmatan lilalamin limakani wa zamani, where Islam was born to provide peace on earth anywhere and anytime. So that educators are obliged to educate their students at least the historical values of the Prophet, who never overreacted to repay the injustices he experienced, instead responding with peace, emotional closeness to the perpetrator, even helping him. These values must always be reminded to students by the learning proses"

In the book Moderation of Religion written by the Indonesian Ministry of Religion Balitbang Team, it is explained that moderation is not only taught by Islam, but also by other religions [11]. In principle, a fair and balanced attitude inherent in the principle of religious moderation can shape a person to have three main characters, namely wisdom, purity, and courage. In other words, being moderate in religion, always choosing the middle way, will be easier to realize if someone has an adequate breadth of religious knowledge so that they can act wisely, resist temptation so that they can be sincere without being burdened, and not selfish with their own interpretation of the truth so they dare to admit interpretation of the truth of others [12].

In an effort to create harmony in the life of the nation and religion, it requires religious moderation, which is a religious attitude that is being or is in the middle and not excessive. Does not claim to be the most correct person or group, does not use extreme theological legitimacy, does not use force let alone violence, and is neutral and does not have any affiliation with certain political interests or forces. This attitude of moderation needs to be socialized, educated, and cultivated by the role models of religious educators. A different matter was stated by Husnaini Jamil, Nurhasanah. They said that:

"The way to integrate the concept of religious moderation in the learning process is by using the discussion method without coercing an opinion on a matter can be an example of religious moderation"

"As an educational institution as well as an institution under the auspices of the Ministry of Religion, it must contribute in spreading the value of moderation to students through learning. Fiqh learning can be a forum for planting the value of Islamic moderation by presenting the concept of Problem Based Learning which requires students to open broad and open insights about the differences in Islamic law applied in society so that they are able to position themselves to be in the middle and act moderately in responding to existing differences. By cultivating moderate values, it is hoped that PTKIN can prepare Indonesian citizens who are Muslim while maintaining the values of wisdom, tolerance and non-radicalism. "

Each lecturer has a very important role in promoting religious moderation in various ways according to the conditions and interests of the class. But the most important thing is how their understanding and perceptions are related to moderation, if the lecturers as the spearhead of planting religious moderation values within the scope of higher education have a comprehensive understanding, the value transformation process can be carried out at any time and in any momentum, including in the learning process in class. Another important thing is the synergy between all institutional components in implementing the value of religious moderation. 


\section{Conclusion}

The understanding of the concept of religious moderation is not new in Islamic universities, since it was promoted by the Ministry of Religion as one of the priority programs, information and literature on this subject has been widely available, both in the form of religious moderation guidebooks, journals, and even on social media. Therefore, the lecturers at Islamic institute of Muhammadiyah sinjai, basically already understand the concept of religious moderation and understand its essence. As with interviews with several lecturers, it can be concluded that Islamic higher education plays an important role in spreading the values of religious moderation and the parties who fight the most in this case are the lecturers who have the responsibility of transforming knowledge and value inside and outside the classroom. Religious subjects are not only about Islamic subjects but also general subjects, making lecturers integrate religious moderation in the learning process with different methods. This really depends on the conditions and interests of the students they teach. Therefore, a general framework is needed in integrating the value of religious moderation in the learning process. In addition, the synergy of the entire campus will also greatly support the process of cultivating the value of religious moderation.

\section{References}

[1] S. Wekke, "Religious Education and Tolerance: Learning Process in High School of RELIGIOUS EDUCATION AND TOLERANCE : LEARNING PROCESS IN HIGH SCHOOL OF,” J. Civ. Educ., vol. 3, no. 3, pp. 137-141, 2017.

[2] N. Sary, "Mencegah Penyebaran Paham Radikalisme Pada Sekolah," Manthiq, vol. 2, no. 2, pp. 191-200, 2017

[3] E. Sutrisno, "Aktualisasi Moderasi Beragama di Lembaga Pendidikan,” J. Bimas Islam, vol. 12, no. 2, pp. 323-348, 2019, doi: 10.37302/jbi.v12i2.113.

[4] M. Informasi and P. Islam, "PENGEMBANGAN PEMBELAJARAN PAI BERWAWASAN ISLAM WASATIYAH: UPAYA MEMBANGUN SIKAP MODERASI BERAGAMA PESERTA DIDIK," vol. 18, no. 1, pp. 89-110, 2019.

[5] W. E. Wahyudi, "Tantangan Islam Moderat di Era Disruption," Proc. Annu. Conf. Muslim Sch., no. Series 2, pp. 922-928, 2018, [Online]. Available: http://proceedings.kopertais4.or.id/index.php/ancoms/article/view/192.

[6] PENDIS, "Tradisi Ngopi Kaum Santri Penguatan Moderasi Beragama di PTKI," Kemenag, 2018.

[7] C. D. Diem and U. Abdullah, "Promoting multiculturalism: Teachers ' English proficiency and multicultural education in Indonesia," vol. 10, no. 1, pp. 46-58, 2020.

[8] "Designing and Conducting Mixed Methods Research," Australian and New Zealand Journal of Public Health, vol. 31, no. 4. pp. 388-388, 2007, doi: 10.1111/j.1753-6405.2007.00096.x.

[9] D. N. Ummah, E. A. Rohmatin, and B. Hasanah, "Pentingnya Moderasi Rahmatal lil Alamin Pendahuluan Pembahasan Tidak Terlalu Ekstrim Ke Kanan dan Ke Kiri,” 2018.

[10] R. Ramli, "Moderasi Beragama bagi Minoritas Muslim Etnis Tionghoa di Kota Makassar," KURIOSITAS Media Komun. Sos. dan Keagamaan, vol. 12, no. 2, pp. 135-162, 2019, doi: 10.35905/kur.v12i2.1219.

[11] T. Penyusun, Moderasi Beragama, vol. 53, no. 9. 2013.

[12] A. Wibowo, "Kampanye Moderasi Beragama di Facebook: Bentuk dan Strategi Pesan," Edugama J. Kependidikan dan Sos. Keagamaan, vol. 5, no. 2, pp. 85-103, 2019, doi: 10.32923/edugama.v5i2.971. 